\title{
ANALISIS KADAR C-REACTIVE PROTEIN PASIEN LANJUT USIA DENGAN KOMORBID YANG TERKONFIRMASI POSITIF COVID-19 DI RSUD PASAR REBO
}

\author{
Enny Khotimah', Amalia ${ }^{2}$ \\ Fakultas Ilmu Kesehatan dan Teknologi, Universitas Binawan \\ Email : ennykesehatan17@gmail.com \\ Fakultas Ilmu Kesehatan dan Teknologi, Universitas Binawan \\ Email: amalialia221@gmail.com
}

\begin{abstract}
ABSTRAK
Coronavirus Disease 2019 (COVID-19) adalah penyakit yang disebabkan oleh Severe Acute Respiratory Syndrome Coronavirus 2 (SARS-CoV-2). Kasus infeksi SARS-CoV-2 yang parah ditandai dengan respons inflamasi sistemik pada pernapasan akut. Respon inflamasi dapat diperiksa dengan tes laboratorium dengan C-Reactive Protein. Tujuan dari penelitian ini adalah untuk mengetahui kadar CRP pada pasien lanjut usia dengan penyakit penyerta yang terkonfirmasi positif COVID-19. Jenis penelitian ini adalah deskriptif kuantitatif dengan desain cross sectional menggunakan teknik accidental sampling diperoleh sampel sebanyak 56 pasien. Penelitian ini dilakukan di Rumah Sakit Pasar Rebo. Berdasarkan uji statistic univariat, distribusi frekuensi laki-laki 29 orang (51,8\%) sedangkan perempuan 27 orang $(48,2 \%)$, kelompok lansia dengan kelompok tertinggi berada pada kelompok lansia dengan rentang usia 65-69 tahun. sebanyak 22 orang (39,3\%), pasien lansia dengan penyakit penyerta Hipertensi mendominasi sebanyak 18 orang $(32,1 \%)$. Hasil pemeriksaan laboratorium menunjukkan adanya peningkatan kadar C-Reactive Protein yang bervariasi, hal ini disertai dengan kondisi pasien yang memiliki penyakit penyerta secara klinis. COVID-19 pada lansia juga memperparah gejala dan perjalanan penyakit COVID-19, akibat penurunan fungsi imun, system imun organ dan banyak penyakit penyerta klinis yang terjadi.
\end{abstract}

Kata kunci: COVID-19, C-Reactive Protein, Lanjut Usia, Komorbiditas

\begin{abstract}
Coronavirus Disease 2019 (COVID-19) is a disease caused by Severe Acute Respiratory Syndrome Coronavirus 2 (SARS-CoV-2). Severe cases of SARS-CoV-2 infection are characterized by a systemic inflammatory response in acute respiration. The inflammatory response can be checked by laboratory tests with C-Reactive Protein. The purpose of this study was to determine CRP levels in elderly patients with comorbidities who were confirmed positive for Covid-19. This type of research is descriptive quantitative with a cross-sectional design using accidental sampling technique obtained a sample of 56 patients. This research was conducted at Pasar Rebo Hospital. Based on the univariate statistical test, the frequency distribution of males was 29 people (51.8\%) while women were 27 people (48.2\%), the elderly group with the highest group was in the elderly group with an age range of 65-69 years as many as 22 people (39.3\%), elderly patients with comorbid Hypertension dominate as many as 18 people (32.1\%). The results of laboratory examinations showed an increase in levels of C-Reactive Protein which varied, this was accompanied by the condition of patients who had clinical comorbidities. Covid-19 in the elderly also worsens the symptoms and course of Covid-19, due to decreased immune function, the immune system of organs and the many clinical comorbidities that occur.
\end{abstract}

Keywords: Covid-19, C-Reactive Protein, Elderly, Comorbid 


\section{PENDAHULUAN}

Penyakit Corona virus Disease 2019 (COVID-19 )adalah penyakit yang disebabkan oleh Severe Acute Respiratory Syndrome Coronavirus 2 (SARS-CoV2), penyakit ini ditemukan pada akhir tahun 2019 di Wuhan, China. VirusSARS$\mathrm{CoV}-2$ menyerang saluran pernapasan dengan gejala umum yaitu demam disertai batuk kering, sesak napas dan pada kasus berat dapat menyebabkan pneumonia, gagal ginjal, sindrom pernapasan akut serta yang lebih fatal dapat menyebabkan kematian(Sugihantono Anung., dkk 2020).

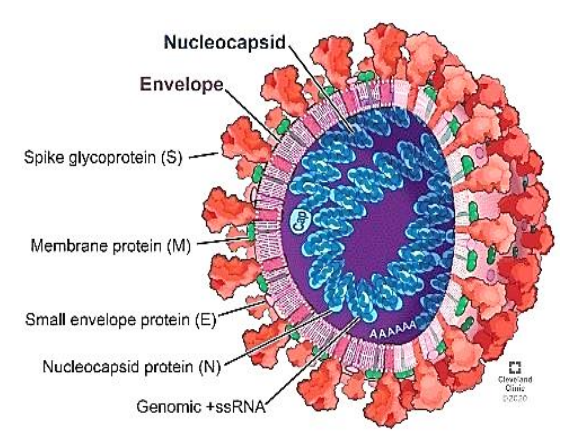

\section{Gambar1.StrukturVirusSARS-CoV2}

Penyebaran COVID-19 yang bersifat zoonosis dapat menular dari hewan kemanusia, selain itu virus ini juga dapat menyebar dari manusia kemanusia yang diikuti dengan penularan virus melalui droplet atau percikan cairan ludah dan pernapasan(Nanshan Chen et al.,2020). Penyebarannya yang sangat signifikan hingga kepenjuru dunia membuat penyakit ini ditetapkan oleh World Health Organization (WHO) sebagai pandemic(Omrani-Nava et al., 2020). WHO mencatat kasus di Asia tenggara mencapai5.924.483 pada tanggal 9 Agustus 2021 (WHO, 2021).Di Indonesia sendiri COVID-19 pertama kali dilaporkan pada awal Maret 2020 dari sejak itulah kasus COVID-19 semakin meningkat setiap harinya. Menurut data dari gugus tugas percepatan penanganan COVID-19 Republik Indonesia hingga tanggal 9Agustus2021 kasus terkonfirmasi positif COVID-19 mencapai 3.686 .740 dengan tingkat kematian mencapai 108.571 orang dengan kasus aktif sebanyak 448.508 orang dan terkonfirmasi sembuh 3.129 .661 orang(Gugus Tugas Percepatan Penanganan Covid19 RI, 2021).

Pemeriksaan laboratorium dibutuhkan untuk dapat menentukan seseorang terpapar COVID-19 yang terdiri dari pemeriksaan utama dan pemeriksaan penunjang. Pemeriksaan utama untuk mendiagnosis COVID-19 dengan menggunakan Real Time Reverse Transcription Quantification Polimerase Chain Reaction (RT-PCR) berbasis molekuler menggunakan sampel swab nasofaring dan orofaring selain itu, pemeriksaan penunjang laboratorium lainnya yaitu tes diagnostic cepat berdasarkan deteksi antigen atau Ag-RDT, tes antibody yang dapat mendeteksi antibody sebagai respons infeksi SARSCOV-2, biakan mikroorganisme, uji kepekaan dari sampel saluran pernapasan, serta pemeriksaan hematologi, kimia klinik, serologis pemeriksaan biomarker inflamasi(Tiongkok, 2020).

Pada infeksi SARS-COV-2 dengan kasus berat dapat menimbulkan pneumonia yang ditandai dengan adanya respon inflamasi sistemik pada pernapasan akut. Respon inflamasi dapat diperiksa dengan pemeriksaan biomarker atau penanda inflamasi yang mana merupakan salah satu pemeriksaan penunjang untuk melihat adanya inflamasi akibat infeksi SARS-COV-2. Pemeriksaan laboratorium sebagai penanda respon inflamasi pada tubuh dapat dideteksi salah satunya dengan pemeriksaan C-Reactive Protein(CRP) dimana CRP dapat membantu sebagai penanda inflamasi prognostic potensial yang cukup spesifik(Smilowitz et al., 2021).

Penelitian mengenai kadar $C$ Reactive Protein pada pasien COVID-19 sudah dilakukan.(Nanshan Chen et al., 2020) menyebutkan terjadi peningkatan kadar CRP sebesar $86 \%$ pada pasien 
Tabel.1 Karakteristik Sampel

\begin{tabular}{llll}
\hline No & Karakteristik Sampel & N & \% \\
\hline $1 \quad$ Jenis Kelamin & 29 & $51,8 \%$ \\
& A. Laki-laki & 27 & $48,2 \%$ \\
\hline & B. Perempuan & $\mathbf{5 6}$ & $\mathbf{1 0 0 \%}$ \\
\hline \multicolumn{2}{l}{ Total } & 18 & $32,1 \%$ \\
& Usia & 22 & $39,3 \%$ \\
& A. Lansia Dini & 16 & $28,6 \%$ \\
& B. Lansia & & $\mathbf{1 0 0 \%}$
\end{tabular}

dewasa hingga lansia yang terkonfirmasi positif COVID-19 beserta kondisi komorbid. Penelitian lain oleh(Wang et al., 2020) dari data klinis dan laboratorium pasien COVID-19 menunjukkan bahwa pasien dewasa dengan tingkat keparahan sedang menunjukkan peningkatan CRP sebesar 7,7\% yang kemudian berubah menjadi kasus yang parah sedangkan pada pasien dengan tingkat keparahan yang berat memiliki peningkatan kadar CRP sebesar $43,8 \%$.

Peningkatan kadar C-Reactive Protein ini merupakan salah satu factor resiko yang berkaitan dengan kematian, karena menurut studi oleh (Hwang et al., 2020) angka kematian tertinggi dilaporkan pada kelompok lanjut usia dengan komorbiditas tertentu seperti penyakit jantung, diabetes, hipertensi, penyakit gagal ginjal sehingga parameter ini juga dapat COVID-19 meskipun harus diperlukannya studi lebih lanjut.

\section{METODE PENELITIAN}

Jenis penelitian yang dilakukan adalah deskriptif kuntitatif untuk mendeskripsikan kadar C-Reactive Protein pada pasien lanjut usia dengan komorbid yang terkonfirmasi positif COVID-19 di RSUD Pasar Rebo dengan desain penelitian Cross-Sectional dimana pengumpulan data kadar C-Reactive
Protein pada pasien lanjut usia dengan komorbid yang terkonfirmasi positif COVID-19 dilakukan bersamaan secara serentak dalam satu waktu.

Pengambilan sampel pada penelitian ini dilakukan menggunakan teknik accidental sampling dengan besaran sampel yang ditentukan berdasarkan criteria inklusi dan ekslusi sehingga didapatkan sebanyak 56 sampel. Data yang digunakan adalah data sekunder berdasarkan data dari instalasi laboratorium patologi klinik dan rekam medic RSUD Pasar Rebo. Analisis data menggunakan uji Univariat untuk mendeskripsikan karakteristik dari masing-masing variable penelitian dan mengguanakan crosstab untuk mendeskripsikan sebaran hasil penelitian berdasarkan karakteristik sampel.

HASIL DAN PEMBAHASAN

\section{A. Karakteristik Sampel Penelitian Berdasarkan Jenis Kelamin dan Kelompok Lanjut Usia}

Berdasarkan data karakteristik yang diperoleh pada tabel 1 , jenis kelamin lakilaki lebih mendominasi pada pasien COVID-19 di RSUD Pasar Rebo yaitu berjumlah 29 orang dengan presentase sebesar 51,8\% sedangkan jenis kelamin perempuan berjumlah 27 orang dengan presentase sebesar 48,2 \%. Pasien 
COVID-19 yang didominasi oleh lakilaki juga sesuai dengan beberapa penelitian sebelumnya salah satunya pada penelitian(Zhang et al., 2020) jenis kelamin laki-laki pada penelitian tersebut yaitu sebesar $50,7 \%$ dibandingkan dengan perempuan sebesar $49,3 \%$. Pada peningkatan risiko infeksi SARS-CoV-2 jenis kelamin laki-laki lebih sering ditemui mengalami keparahan dari penyakit COVID-19(Zhao et al., 2020).

Pada karakteristik usia, kelompok lanjut usia yang mendominasi pada pasien COVID-19 di RSUD Pasar Rebo adalah kelompok lansia sebanyak 22 orang dengan presentase 39,3\%.Diikuti oleh kelompok lansia dini yaitu sebanyak 18 orang dengan presentase 32,1 \% dan kelompok lansia resiko tinggi sebanyak 16 orang dengan presentase sebesar 28,6\%.Pada pasien lanjut usia cenderung mengalami disfungsi organ multi sistem dan seiring bertambahnya usia dan diketahui adanya gangguan pada komponen sistem imun baik alami maupun adaptif, sehingga dapat memperburuk kondisi pasien(Yuliana, 2020).

\section{B. Komorbid Pada Paien Lanjut Usia Terkonfrimasi Positif COVID-19}

Tabel 2. Komorbid Klinis Pada Pasien Lansia COVID-19

\begin{tabular}{lcc}
\hline Komorbid Klinis & $\mathbf{N}$ & $\mathbf{\%}$ \\
\hline A. Hipertensi & 18 & $32,1 \%$ \\
B. Pneumonia & 14 & $25,0 \%$ \\
C. Diabetes Mellitus & 16 & $28,6 \%$ \\
D. Tuberkulosis & 1 & $1,8 \%$ \\
E. Penyakit Jantung & 3 & $5,4 \%$ \\
$\quad$ Koroner & 1 & $1,8 \%$ \\
F. Gagal Ginjal & 3 & $5,4 \%$ \\
$\quad$ Kronis & & \\
G. Penyakit Paru & & \\
$\quad$ Obstruktif Kronis & & \\
$\quad$ (PPOK) & & \\
$\quad$ Total & $\mathbf{5 6}$ & $\mathbf{1 0 0} \%$ \\
\hline
\end{tabular}

Berdasarkan data pada tabel 2 komorbid klinis pada pasien lanjut usia yang terkonfirmasi positif COVID-19 menunjukkan bahwa penyakit Hipertensi dengan tingkat penderita yang tinggi sebanyak 18 orang dengan presentase $32,1 \%$, Pneumonia sebanyak 14 orang dengan presentase $25 \%$ diikuti dengan Diabetes Melitus sebanyak 16 orang dengan presentase 28,6\%, Tuberculosis sebanyak 1 orang dengan presentase $1,8 \%$, Penyakit Jantung Koroner sebanyak 3 orang denga prosentase 5,4\%, Gagal Ginjal Kronis sebanyak 1 orang dengan presentase $1,8 \%$ serta Penyakit Paru Obstruktif Kronik (PPOK) sebanyak 3 orang dengan presentase 5,4\%. Kondisi komorbid pada lanjut usia mencentuskan badai sitokin yang diinduksi oleh virus SARS CoV-2 yang dapat menyebabkan gagal napas hingga mengancam jiwa (Perrotta et al., 2020). Komorbid klinis hipertensi yang dominan juga sesuai dengan penelitian sebelumnya yaitu penelitianhipertensi sebagai penyakit penyerta yang paling sering ditemukan pada pasien lanjut usia yang terkonfirmasi positif COVID-19(Azwardkk., 2020) dan diikuti Diabetes mellitus sebesar 11\%.Infeksi paru pada COVID-19 menyebabkan peningkatan beban kerja pada jantung serta pada penyakit diabetes mellitus menyebabkan kadar gula darah tinggi yang mengakibatkan kesulitan dalam kontrol infeksi sehingga dapat memperburuk keadaan(Liu et al., 2020).

Distribusi C. Kadar CRP Pada Pasien COVID-19 Berdasarkan Kelompok Usia

Berikut adalah hasil distribusi frekuensi pasien lanjut usia yang terkonfirmasi positif COVID-19 di RSUD Pasar Rebo seperti yang terlihat pada tabel 3 . Berdasarkan tabel 3, hasil pemeriksaan CRP berdasaarkan kelompok usia pada kelompok lansia dini yaitu dengan rentang umur 55-64 tahun pada kadar $12 \mathrm{mg} / \mathrm{L}$ didapatkan sebanyak 9 orang $(16,1 \%)$, pada kadar $96 \mathrm{mh} / \mathrm{L}$ didapatkan sebanyak 1 orang $(1,8 \%)$. 
Sedangkan pada kelompok lansia dengan rentang umur 65-69 tahun pada kadar $12 \mathrm{mg} / \mathrm{L}$ didapatkan sebanyak 7 orang $(12,5 \%)$, pada kadar $24 \mathrm{mg} / \mathrm{L}$ didapatkan hasil sebanyak9 orang $(16,1 \%)$, pada kadar $48 \mathrm{mg} / \mathrm{L}$ didapatkan sebanyak 3 orang $(5,4 \%)$, pada kadar $96 \mathrm{mg} / \mathrm{L}$ didapatkan sebanyak 1 orang $(1,8 \%)$. Sedangkan pada kelompok lanjut usia dengan resiko tinggi pada kadar $12 \mathrm{mg} / \mathrm{L}$ didapatkan sebanyak 4 orang $(7,1 \%)$, pada kadar $24 \mathrm{mg} / \mathrm{L}$ didapatkan sebanyak 2 orang $(3,6 \%)$, pada kadar 48 $\mathrm{mg} / \mathrm{L}$ didapatkan sebanyak 7 orang (12,5\%) pada kadar $96 \mathrm{mg} / \mathrm{L}$ didapatkan sebanyak 3 orang $(5,4 \%)$

Padapemeriksaan CRP memiliki kelemahan yaitu dimana protein ini menghindari adanya fenomena post zone yang disebabkan oleh kelebihan antigen. Untuk mengatasi hal tersebut dalam pemeriksaan CRP dengan menggunakan metode aglutinasi lateks apabila hasil negatif dapat diulang dengan pengenceran yaitu menggunakan sampel sebanyak 20 ul untuk menghindari adanya fenomena post zone sebagai akibat kelebihan antigen.Kesalahan pada pemeriksaan CRP ini juga tidak bisa ditepiskan karena pengamatan ada atau tidaknya aglutinasi menggunakan analisis mata. Penyimpanan sampel serum yang berbeda-beda dapat mempengaruhi kestabilan sampel serum (Putri et al., 2021). Hal ini dapat memberikan interpretasi hasil yang kurang tepat. Selain kelemahan

Tabel 3. Distribusi Kadar CRP Pada Pasien COVID-19 Berdasarkan Jenis Kelamin

\begin{tabular}{|c|c|c|c|c|c|c|c|c|}
\hline \multirow{3}{*}{ Kelompok Usia } & \multicolumn{5}{|c|}{ Kadar C-Reactive Protein } & & \multirow{2}{*}{\multicolumn{2}{|c|}{$96 \mathrm{mg} / \mathrm{L}$}} \\
\hline & \multicolumn{2}{|c|}{$12 \mathrm{mg} / \mathrm{L}$} & \multicolumn{2}{|c|}{$24 \mathrm{mg} / \mathrm{L}$} & \multicolumn{2}{|c|}{$48 \mathrm{mg} / \mathrm{L}$} & & \\
\hline & $\mathbf{n}$ & $\%$ & $\mathbf{n}$ & $\%$ & $\mathbf{n}$ & $\%$ & $\mathbf{n}$ & $\%$ \\
\hline $\begin{array}{l}\text { Lansia Dini } \\
\text { (55-64 Tahun) }\end{array}$ & 9 & 16,1 & 1 & 1,8 & 9 & 16,1 & 1 & 1,8 \\
\hline $\begin{array}{l}\text { Lansia } \\
\text { (65-69 Tahun) }\end{array}$ & 7 & 12,5 & 9 & 16,1 & 3 & 5,4 & 1 & 1,8 \\
\hline $\begin{array}{l}\text { Lansia Resiko } \\
\text { Tinggi } \\
\text { (>70 Tahun) }\end{array}$ & 4 & 7,1 & 2 & 3,6 & 7 & 12,5 & 3 & 5,4 \\
\hline $\begin{array}{l}\text { Total } \\
\mathrm{N}=56 \\
\%=100 \%\end{array}$ & 20 & 35,7 & 12 & 21,5 & 19 & 34 & 5 & 9 \\
\hline $\begin{array}{l}\text { tidak spesifik un } \\
\text { inflamasi dalan } \\
\text { hanya dapat } \\
\text { inflamasi atau } \\
\text { Terjadinya ag } \\
\text { butiran halus } \\
\text { menunjukkan ti } \\
\text { Pemeriksaan } \\
\text { lateks dengan } \\
\text { dapat memberil } \\
\text { sehingga dip } \\
\text { bertingkat pa }\end{array}$ & $\begin{array}{l}\text { dap } \\
\text { buh } \\
\text { hat } \\
\text { eksi } \\
\text { hasi } \\
\text { pad } \\
\text { CR } \\
\text { me } \\
\text { sent } \\
\text { hasi } \\
\text { kan } \\
\text { s }\end{array}$ & $\begin{array}{l}\text { at lo } \\
\text { ters } \\
\text { ada } \\
\text { tul } \\
\text { bet } \\
\text { be } \\
\text { sam } \\
\text { gluti } \\
\text { gi } \\
\text { if pa } \\
\text { gence } \\
\text { ul }\end{array}$ & & $\begin{array}{l}\text { peme } \\
\text { latek } \\
\text { dapat } \\
\text { karen } \\
\text { alat t } \\
\text { menun } \\
\text { yang } \\
\text { usia y } \\
\text { 19. Ti } \\
\text { infeksi } \\
\text { tingkat }\end{array}$ & $\begin{array}{l}\text { saan } \\
\text { eleb } \\
\text { neml } \\
\text { peng } \\
\text { yang } \\
\text { rdas } \\
\text { kan } \\
\text { up } \\
\text { terl } \\
\text { yi re } \\
\text { SAl } \\
\text { para }\end{array}$ & $\begin{array}{l}\text { P } \mathrm{m} \\
\text { pada } \\
\text { an h } \\
\text { innya } \\
\text { angka } \\
\mathrm{n} \text { pa } \\
\text { rjadin } \\
\text { tif pa } \\
\text { irmas } \\
\text { inya } \\
\text { toV2 } \\
\text { peny }\end{array}$ & $\begin{array}{r}\text { etod } \\
\text { Ja } \\
\text { tame } \\
\text { tabe } \\
\text { pas } \\
\text { psiti }\end{array}$ & $\begin{array}{l}\text { inasi } \\
\text { yaitu } \\
\text { cepat } \\
\text { dan } \\
\text { 16) } \\
\text { atas } \\
\text { xatan } \\
\text { anjut } \\
\text { VID- } \\
\text { pada } \\
\text { nkan } \\
\text { rnya }\end{array}$ \\
\hline
\end{tabular}


respon inflamasi akut. Penelitian sebelumnya menunjukkan bahwa meningkatnya kadar CRP pada pasien rawat inap dengan COVID-19 berkorelasi dengan tingkat keparahan penyakit, kematian dan gagal napas (Sharifpour et al., 2020). Pada sistem imun lanjut usia baik alami maupun adaptif terjadi gangguan produksi mediator inflamasi dan sitokin yang disebut inflamagging atau inflamasi kronik ringan sistemik yang dapat terjadi pada penuaan secarafisiologis(Liu et al., 2020). Peningkatan kadar CRP merupakan faktor prognosis buruk pada pasien lansia. Selama adanya demam selama perawatan di rumah sakit dan terjadinya peningkatan kadar CRP berkaitan dengan kematian pada pasien COVID-19(Hwang et al., 2020).

\section{SIMPULAN}

Pada penelitian ini dapat disimpulkan bahwa hasil pemeriksaan laboratorium terhadap pemeriksaan penunjuang COVID19 yaitu pada pemeriksaan kadar $C$ Reactive Protein menunjukkan adanya peningkatan yang variatif, hal ini diiringi oleh keadaan pasien yang sebelumnya juga memiliki komorbid klinis. Infeksi SARSCov-2 pada pasien lanjut usia juga semakin memperburuk kondisi pasien dikarenakan adanya penurunan fungsi imun. Jenis kelamin laki-laki lebih mendominasi yaitu sebanyak 29 orang $(51,8 \%)$ dibandingkan dengan perempuan yaitu sebanyak 27 orang $(48,2 \%)$. Kelompok lanjut usia dengan kelompok tertinggi yaitu pada kelompok lanjut usia dengan rentang umur 65-69 tahun sebanyak 22orang (39,3\%). Hipertensi sebagai komorbid klinis lebih mendominasi disbanding penyakit penyerta lainnya yaitu sebanyak 18 orang $(32,1 \%)$ dari total keseluruhan 56 pasien.

\section{UCAPAN TERIMA KASIH}

Terima kasih kepada Rumah Sakit Umum Daerah Pasar Rebo yang telah memberikan kesempatan dalam melakukan penelitian, terima kasih kepada Universitas Sari Mutiara Indonesia dan LPPM USMIndonesia.

\section{DAFTAR PUSTAKA}

Azwar, M. K., Setiati, S., Rizka, A., Fitriana, I., Saldi, S. R. F., \& Safitri, E. D. (2020) (2020) 'Clinical Profile of Elderly Patients with COVID-19 hospitalised in Indonesia's National General Hospital.' Available at: https://scholar.ui.ac.id/en/publications/clini cal-profile-of-elderly-patients-with-covid19-hospitalised-i.

dr. Anung Sugihantono, M.Kes; dr. Erlina Burhan, Sp.P (K)., M.Sc., Ph.D (Perhimpunan Dokter Paru Indonesia); dr. Agus Dwi Susanto, Sp.P (K), FISR, FAPSR (Perhimpunan Dokter Paru Indonesia); Dr. Triya Damayanti, PhD, Sp.P(K) (Perhimpunan Dokter Paru Indone, F. (Perhimpunan D. S. P. D. I.-P. (2020) 'PEDOMAN PENCEGAHAN DAN PENGENDALIAN CORONAVIRUS DISESASE (COVID19) revisi ke 5', pp. 1-214.

Gugus Tugas Percepatan Penanganan Covid19 RI (2021) Data sebaran Covid19. Available at: https://covid19.go.id/petasebaran (Accessed: 7 February 2021).

Hwang, J. et al. (2020) 'Prognostic Factors of COVID-19 Infection in Elderly Patients: A Multicenter Study', Journal of Clinical Medicine, 9(12), p. 3932. doi: $10.3390 / \mathrm{jcm} 9123932$.

Liu, K. et al. (2020) 'Clinical features of COVID-19 in elderly patients: A comparison with young and middle-aged patients', Journal of Infection, 80(6), pp. e14-e18. doi: 10.1016/j.jinf.2020.03.005.

Nanshan Chen*, Min Zhou*, Xuan Dong*, Jieming $\mathrm{Qu}^{*}$, Fengyun Gong, Yang Han, Yang Qiu, Jingli Wang, Ying Liu, Yuan 
Wei, Jia'an Xia, Ting Yu, Xinxin Xinxin Zhang, L. Z. (2020) 'Epidemiological and clinical characteristics of 99 cases of 2019 novel coronavirus pneumonia in Wuhan, China: a descriptive study', (January).

Omrani-Nava, V. et al. (2020) 'Evaluation of hepatic enzymes changes and association with prognosis in COVID-19 patients', Hepatitis Monthly, 20(4), pp. 05. doi: 10.5812/hepatmon.103179.

Perrotta, F. et al. (2020) 'COVID - 19 and the elderly: insights into pathogenesis and clinical decision - making', Aging Clinical and Experimental Research, 32(8), pp. 1599-1608. doi: 10.1007/s40520-02001631-y.

Putri, W. R. et al. (2021) 'PENURUNAN KADAR BILIRUBIN TOTAL SERUM YANG DIENCERKAN', 6(1), pp. 23-28.

Sharifpour, M. et al. (2020) 'C-Reactive protein as a prognostic indicator in hospitalized patients with COVID-19', PLoS ONE, 15(11 November), pp. 1-10. doi: 10.1371/journal.pone.0242400.

Smilowitz, N. R. et al. (2021) 'C-reactive protein and clinical outcomes in patients with COVID-19', European Heart Journal, pp. 1-10. doi: 10.1093/eurheartj/ehaa1103.

Tiongkok, R. (2020) 'Tes Diagnostik untuk SARS-CoV-2', (September).

Utama, I. M. G. D. L. (2016) 'Uji Diagnostik C-Reactive Protein, Leukosit, Nilai Total Neutrofil dan Suhu Anak Deman dengan Penyebab yang Tidak Diketahui', Sari Pediatri, 13(6), p. 412. doi: 10.14238/sp13.6.2012.412-9.

Wang, G. et al. (2020) 'C-reactive protein level may predict the risk of COVID-19 aggravation', Open Forum Infectious Diseases, 7(5), pp. 1-5. doi: 10.1093/ofid/ofaa153.

Yuliana (2020) 'Wellness and Healthy Magazine', Parque de los afectos. Jóvenes que cuentan, 2(February), pp. 124-137.

Zhang, J.-J. et al. (2020) 'Clinical characteristics of 140 patients infected with SARS-CoV-2 in Wuhan, China.', Allergy, 75(7), pp. 1730-1741. Available at:

https://www.unboundmedicine.com/medli ne/citation/32077115/Clinical_characteristi cs_of_140_patients_infected_with_SARS_ CoV_2_in_Wuhan_China_.

Zhao, K. et al. (2020) 'Clinical features in 52 patient', European Journal of Clinical Microbiology \& Infectious Diseases. 